\title{
Continent Epispadias
}

National Cancer Institute

\section{Source}

National Cancer Institute. Continent Epispadias. NCI Thesaurus. Code C123177.

Epispadias with urinary continence. 